\title{
Correction to: Observation of Anomalously Strong Penetration of Terahertz Electric Field Through Terahertz-Opaque Gold Films Into a GaAs/AIGaAs QuantumWell
}

\author{
S. D. Ganichev ${ }^{1}$ - S. N. Danilov ${ }^{1} \cdot$ M. Kronseder ${ }^{1}$ - D. Schuh ${ }^{1} \cdot$ I. Gronwald ${ }^{1}$. \\ D. Bougeard' - E. L. Ivchenko² A. Ya. Shul'man³
}

Published online: 9 December 2021

(c) The Author(s) 2021

\section{Correction to: Journal of Infrared, Millimeter, and Terahertz Waves (2021) https://doi.org/10.1007/s10762-020-00717-y}

The article "Observation of Anomalously Strong Penetration of Terahertz Electric Field Through Terahertz-Opaque Gold Films Into a GaAs/AlGaAs QuantumWell”, written by S. D. Ganichev, S. N. Danilov, M. Kronseder, D. Schuh, I. Gronwald1, D. Bougeard, E. L. Ivchenko, and A. Ya. Shul'man, was originally published Online First without Open Access. After publication, the author decided to opt for Open Choice and to make the article an Open Access publication. Therefore, the copyright of the article has been changed to (C) The Author(s) 2021 and the article is forthwith distributed under the terms of the Creative Commons Attribution 4.0 International License (http://creativecommons. org/licenses/by/4.0/), which permits use, duplication, adaptation, distribution, and reproduction in any medium or format, as long as you give appropriate credit to the original author(s) and the source, provide a link to the Creative Commons license, and indicate if changes were made.

The original article has been corrected.

The original article can be found online at https://doi.org/10.1007/s10762-020-00717-y.

S. D. Ganichev

sergey.ganichev@physik.uni-regensburg.de

1 Terahertz Center, University of Regensburg, 93040 Regensburg, Germany

2 Ioffe Physico-Technical Institute, 194021 St. Petersburg, Russia

3 Kotelnikov Institute of Radioengineering and Electronics RAS, 125009 Moscow, Russia 
Open Access This article is licensed under a Creative Commons Attribution 4.0 International License, which permits use, sharing, adaptation, distribution and reproduction in any medium or format, as long as you give appropriate credit to the original author(s) and the source, provide a link to the Creative Commons licence, and indicate if changes were made. The images or other third party material in this article are included in the article's Creative Commons licence, unless indicated otherwise in a credit line to the material. If material is not included in the article's Creative Commons licence and your intended use is not permitted by statutory regulation or exceeds the permitted use, you will need to obtain permission directly from the copyright holder. To view a copy of this licence, visit http://creativecommons.org/licen ses/by/4.0/.

Publisher's Note Springer Nature remains neutral with regard to jurisdictional claims in published maps and institutional affiliations. 